\title{
The Role of Surfactant in Respiratory Distress Syndrome
}

\author{
Christopher Cheng-Hwa Ma* and Sze Ma
}

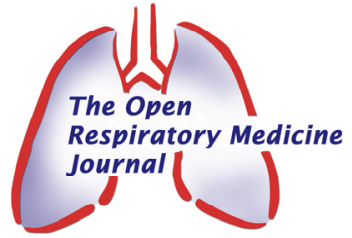

King's College London School of Medicine, London SE1 IUL, UK

\begin{abstract}
The key feature of respiratory distress syndrome (RDS) is the insufficient production of surfactant in the lungs of preterm infants. As a result, researchers have looked into the possibility of surfactant replacement therapy as a means of preventing and treating RDS. We sought to identify the role of surfactant in the prevention and management of RDS, comparing the various types, doses, and modes of administration, and the recent development. A PubMed search was carried out up to March 2012 using phrases: surfactant, respiratory distress syndrome, protein-containing surfactant, protein-free surfactant, natural surfactant, animal-derived surfactant, synthetic surfactant, lucinactant, surfaxin, surfactant protein-B, surfactant protein-C.

Natural, or animal-derived, surfactant is currently the surfactant of choice in comparison to protein-free synthetic surfactant. However, it is hoped that the development of protein-containing synthetic surfactant, such as lucinactant, will rival the efficacy of natural surfactants, but without the risks of their possible side effects. Administration techniques have also been developed with nasal continuous positive airway pressure (nCPAP) and selective surfactant administration now recommended; multiple surfactant doses have also reported better outcomes. An aerosolised form of surfactant is being trialled in the hope that surfactant can be administered in a non-invasive way. Overall, the advancement, concerning the structure of surfactant and its mode of administration, offers an encouraging future in the management of RDS.
\end{abstract}

Keywords: Surfactant, RDS, natural, synthetic, protein-free, protein-containing.

\section{INTRODUCTION}

Respiratory distress syndrome (RDS) is observed in prematurely born infants. Surfactant production is insufficient due to the immature development of type II pneumocytes, which begin to produce surfactant at approximately 20 weeks gestation [1]. Insufficient surfactant leads to reduced pulmonary compliance and increased surface tension [2,3]. This results in increased risk of alveoli collapse at expiration followed by reduction in total surface area for gaseous exchange, as well as the alveolar-capillary diffusion capacity. Hypoxia and hypercapnia develops. The risk and severity of RDS are inversely proportional to the gestational age of the infant at birth [4]. In fact, prior to the introduction of surfactant, RDS was considered to be the leading aetiology of mortality in preterm infants [5]. As a result, much effort has been focussed on the prevention and treatment of RDS.

Many therapeutic strategies have been proposed, but few have shown large benefit. One such therapeutic proposal is the administration of surfactant [6]. Trials have been ongoing since the 1960s with gradual development and refinement of surfactant product [7]. It has been clearly determined from randomised controlled trials that surfactant replacement therapy imparts a significant benefit in the prevention or treatment of RDS [8] The beneficial impact of surfactant has led to enhanced development and research into new surfactant analogues [9]. Two main subtypes have been developed: natural and synthetic. Animal-derived surfactant, also known as natural surfactant, contains a similar

*Address correspondence to this author at the King's College London School of Medicine, London SE1 1UL, UK; Tel: (+44) 07838978 541; E-mail: christopher.ma@kcl.ac.uk morphology to that of human surfactant. Natural surfactant has been considered the superior subtype, due to its greater efficacy in mimicking the action of human surfactant. Animals used in this process include pigs and cows. There are three commonly researched natural surfactants [10]. First, poractant $\left(\right.$ Curosurf $\left.^{\mathbb{B}}\right)$ is derived from minced porcine lungs [11]. Second, beractant $\left(\right.$ Survanta $\left.^{\circledR}\right)$ is a bovine extract [12]. Third, calfactant (Infasurf $^{\circledR}$ ) is another bovine surfactant extracted by broncho-alveolar lavage [13]. The value between the two subtypes has yet to be fully elucidated. Bovine samples are most commonly used followed by porcine extracts. Despite the positive findings when natural surfactant is administered, there are a number of drawbacks, including the lack of cost-effectiveness, inconsistent efficacy, possible anaphylactic shock reaction, and risk of pathogen contamination. It is important to note that the pathogenic risks have not been identified on a clinical level.

In recent years, synthetic surfactant has experienced a surge in breakthroughs to the point of rivalling natural surfactant. The prime factor has been the development of protein-containing synthetic surfactant. Previous synthetic surfactant only contained phospholipids, with colfosceril palmitate $\left(\right.$ Exosurf $\left.^{(B)}\right)$ the most commonly trialled protein-free synthetic surfactant [14]. It had been shown that its therapeutic effect was inferior to that of natural surfactant. The rise of protein-containing synthetic surfactant, such as lucinactant $\left(\operatorname{Surfaxin}^{\mathbb{B}}\right)$, has offered scientists a new avenue to further expand upon our advancement in surfactant as its action has been hypothesised to be as effective as, or even better than, natural surfactant $[15,16]$. The purpose of this review is to identify the key components of surfactant analogues, discuss the trials comparing surfactant types, 
analyse the methods of surfactant administration, and highlight recent developments.

\section{BIOCHEMICAL BACKGROUND OF SURFACTANT ANALOGUES}

\section{Biochemical Structure of Surfactant}

Surfactant composition is derived from $90 \%$ phospholipid and $10 \%$ protein. Phosphatidylcholine (PC) is the main phospholipid class, with dipalmitoylphosphatidylcholine (DPPC) the commonest subtype. Monolayers of DPPC are crucial in the maintenance of surface tension at near zero levels during compression [17]. Surfactant protein A, B, C and D (SP-A, -B, -C and -D) are the four key proteins that have been isolated. Despite forming a small proportion of the surfactant molecule, these proteins are vital to the stabilisation and functioning of surfactant. Without surfactant protein, DPPC is at increased risk of forming semi-crystalline domains during expiration [18]. SP-A and $\mathrm{D}$ are large hydrophilic lectin proteins involved in pulmonary host defence. By binding to apoptotic cells in a $\mathrm{Ca}^{2+}$-dependent manner, SP-A and -D activates phagocytic clearance by alveolar macrophages along with formation of reactive oxygen species and nitrogen intermediates [19] Other mechanisms involve the upregulation of secretory leukoprotease inhibitor (SLPI) [20]. SLPI prevents degradation of matrix metalloproteinase, a molecule involved in antigen apoptosis through the proteolytic breakdown of extracellular matrix components. Release of neutrophil chemotactic factors by alveolar type II pneumocytes is also regulated by SP-A [21]. Studies on animal models with SP-A and -D deficiencies have sought to confirm these findings. Baboons with SP-A and -D deficiencies have demonstrated an increased susceptibility to pulmonary infection [22], while SP-A and -D knockout mice displayed delayed pneumocystis carinii (jiroveci) clearance, reduced proinflammatory cytokines, and enhanced lung injury $[23,24]$. Similar findings were identified in mycobacterium tuberculosis [25] and mycoplasma pulmonis infection [26].

SP-B and -C, on the other hand, play an intricate role in sustaining alveolar ventilation. Because of their small hydrophobic properties, SP-B and -C interact with polar head groups of DPPC to form a surface-active film, which lowers surface tension and allows alveoli to maintain patency. SP-B, in particular, is crucial in the maturation of surfactant. SP-B gene expression is actually prevalent at 24 weeks gestation but maturation onset only occurs at 30 weeks gestation [27]. The high level of hydrophobicity allows numerous bonds to be formed between other molecules [28]. Studies comparing the action of SP-B and -C have found that SP-B displays a greater ability in stabilising film formation [29]. Thus, surfactant extracts containing only SP-B reached significantly lower surface tension in contrast to SP-C containing surfactant extracts. Studies on SP-B gene knockout mice, as well as infants with SP-B deficiency, have demonstrated an incompatibility with life as a result of dysfunctional surfactant action [30,31]. In addition, SP-B has been shown to demonstrate antimicrobial activity, suggesting that pulmonary host defence may involve an interaction between SP-A, -D and -B. Studies on
SP-C have demonstrated less severe findings with SP-C deficient infants developing interstitial lung disease [32].

\section{Natural Surfactant}

Beractant (Survanta ${ }^{\circledR}$ ) is animal surfactant derived from minced bovine lung extract, with the added products of DPPC, palmitic acid and tripalmitin [33]. Surfactant protein concentrations comprise of SP-B and SP-C. These additional products increase its similarity to the composition of human surfactant. Calfactant $\left(\operatorname{Infasurf}^{\mathrm{B}}\right)$ ) is another bovine extract from lung lavage containing DPPC, SP-B and SP-C [34]. Compared to beractant, calfactant has higher phospholipid content $(95 \%$ vs $84 \%)$ and a greater SP-B concentration (5.4ug/umol vs $1.3 \mathrm{ug} / \mathrm{umol}$ ), suggesting improved surfactant effect [35]. In contrast, poractant $\left(\right.$ Curosurf $\left.^{\mathbb{B}}\right)$ is extracted from minced porcine lungs and undergoes a series of purification procedures by centrifuge to remove neutral lipids [10]. SP-B and SP-C are the only two protein types present [36]. The result is a suspension consisting of $99 \%$ polar lipids and 1\% low molecular weight hydrophobic proteins. This superior concentration of phospholipid, as compared to both bovine extracts, is constructed to potentially maximise efficacy.

\section{Synthetic Surfactant}

There are a number of barriers involved in the development of protein-containing synthetic surfactant. Because surfactant proteins interact closely to each other, the precise composition is required for surfactant to function properly. Moreover, the recombinant proteins must be configured correctly with DPPC; this further complicates the model. With regards to SP-B, the hydrophobic expression combined with the numerous disulfide bridges have forced researchers to focus on synthesising key components of the structure [28]. Mimicking of N-terminal and C-terminal formation has been particularly emphasised. Likewise, SP-C has proven tricky to replicate. Its highly hydrophobic nature combined with its small size of 35 amino acid residues and the limited number of side chains makes SP-C an unstable structure [37]. Key to the structure is the alpha helix component. This alpha helix inserts into the lipid bilayer, allowing SP-C to maintain a parallel orientation in relation to the lipid structure. This specific orientation mechanism is one of many that allow the surfactant molecule to maintain its structure.

Despite the intricate challenge, synthetic surfactants containing surfactant protein have demonstrated encouraging results. Lucinactant, also known as Surfaxin ${ }^{\circledR}$, is considered a new-generation synthetic surfactant composed of DPPC, POPG (palmitoyloleoyl phosphatidylglycerol), palmitic acid, and sinapultide, a hydrophobic 21 -amino acid $\mathrm{KL}_{4}$ peptide with the hydrophobic-hydrophilic amino acid pattern of leucine and lysine repeating units [38,39]. Despite its considerably smaller size relative to SP-B, sinapultide replicates SP-B action by mimicking a C-terminal amphipathic helical domain of SP-B. Charged amino acid residues associate with polar heads of phospholipids, while alternating neutrally-charged amino acids interact with fatty acid chains. It is thought that this interface improves spreading and stability of the air-liquid interface. As a means of compensating for the inaccurate replication of SP-B, lucinactant contains a greater concentration of sinapultide 
than the concentration of SP-B found in animal and human surfactant. Moreover, lucinactant has demonstrated a greater resistance to oxidation and protein inhibition in comparison to animal-derived surfactants [40].

\section{COMPARATIVE TRIALS}

\section{Comparison of Natural vs Synthetic Surfactant}

\section{Comparison of Natural vs Protein-Free Synthetic Surfactant}

A Cochrane meta-analysis compared the impact of natural and synthetic protein-free surfactant in the prevention and treatment of RDS [41]. Randomised controlled trials from 1975 to 2000 were sought, with a total of eleven trials accepted under the inclusion criteria (Table 1). The metaanalysis identified that patients of either drug arm demonstrated improvement in reducing mortality related to RDS. However, treatment with natural surfactant displayed significantly better outcomes in contrast to synthetic surfactant with regards to the risk of pneumothorax and mortality. In addition, a lower rate for ventilator support was reported in the natural surfactant cohort.

Only one trial analysed the preventative effect of surfactant on RDS [42]. 871 premature neonates under 29 weeks gestation across a series of centres were randomised to calfactant (calf lung lavage) or colfosceril (synthetic) surfactant. Calfactant was found to significantly reduce the incidence of RDS (calfactant 16\% vs colfosceril 42\%) as well as mortality secondary to RDS (calfactant $1.7 \%$ vs colfosceril 5.4\%). Weaning from mechanical ventilation occurred at a shorter duration in calfactant. However, there was no difference concerning the incidence of overall mortality, bronchopulmonary dysplasia (BPD), and pneumothorax. Interestingly, intraventricular haemorrhage was reported to be increased in the calfactant group (calfactant 39\% vs colfosceril 29.9\%). Nevertheless, this increase in incidence only coincided with grade 1 and 2, which confined the haemorrhage to the ventricles. Neither Hudak nor any of the treatment trials identified an increased risk of severe intraventricular haemorrhage.

\section{Comparison of Natural vs Protein-Containing Synthetic Surfactant}

The anti-inflammatory effects of protein-containing surfactant have been demonstrated in calu-3 monolayer cells cultured from human airway epithelial cells [40]. Cells were treated with normal saline, lucinactant, or beractant.
Indicators of inflammation and tissue remodelling included, transepithelial resistance (TER), paracellular permeability, and expression of interleukin (IL)- 6 and -8 , as well as matrix metalloproteinase (MMP)-2, -7, and -9. It was discovered that cells treated with either lucinactant or beractant demonstrated greater cell viability as compared to normal saline treatment. TER was also significantly greater at 24 and 72 hours in both surfactant groups relative to normal saline $(p<0.001)$. However, at 72 hours, lucinactant cohort demonstrated significantly increased $(p<0.001)$ TER than beractant. In terms of IL levels, IL- 6 was markedly reduced in lucinactant-treated monolayers versus normal saline and beractant groups. Conversely, IL-8 levels showed no difference between the three cohorts at 24 and 72 hours. Analysis of MMP highlighted undetectable levels in both MMP-2 and MMP-9 at 72 hours in all three groups. MMP-7 levels were also undetectable in lucinactant-treated monolayers at both 24 and 72 hours. In contrast, beractant and normal saline cohorts expressed detectable MMP-7 levels at 24 hours with little difference between the two groups. Beractant did reach undetectable levels at 72 hours, while normal saline remained detectable. This suggests that Lucinactant is more effective in preventing the release of proinflammatory mediators, which play a key role in the development of chronic lung disease (CLD), especially BPD.

The SELECT (Safety and Effectiveness of Lucinactant versus Exosurf in a Clinical Trial of RDS in Premature Infants) trial was a multinational, randomised, Phase III, double-blinded, clinical trial that evaluated the effects of protein-containing surfactant against protein-free surfactant and natural surfactant [43] (Table 2). 1294 premature infants at or below 32 weeks gestation with birth weights between 600 and $1200 \mathrm{~g}$ were recruited and distributed to three cohorts: lucinactant $(n=527)$, colfosceril $(n=509)$, and bovine-derived beractant $(n=258)$. Similar mean doses were administered across all three treatment arms within 30 minutes of birth. In comparing beractant with lucinactant, the latter slightly reduced rates of RDS, RDS-related mortality, and overall morality. There was no difference in neonatal morbidities, including pneumothorax.

A randomised, double-blinded, Phase III trial was carried out at around the same time under the title of STAR (Surfaxin Therapy Against RDS) trial comparing proteincontaining surfactant to natural surfactant [44]. Twenty-two centres across Europe, Canada, and the United States recruited 252 very premature infants delivered between 24

Table 1. Trials Comparing Natural and Protein-Free Synthetic Surfactants

\begin{tabular}{|c|c|c|c|c|c|}
\hline Year & Authors & Surfactants Used & Participants & Endpoints of Trial & Results of Trial \\
\hline 1997 & $\begin{array}{l}\text { Hudak et al. } \\
{[42]}\end{array}$ & $\begin{array}{l}\text { 1. Calfactant } \\
\text { 2. Colfosceril }\end{array}$ & $\begin{array}{l}871 \\
\text { Neonates }<29 \text { weeks GA }\end{array}$ & $\begin{array}{l}\text { 1. Incidence of RDS } \\
\text { 2. BPD } \\
\text { 3. Pneumothorax } \\
\text { 4. RDS-related mortality } \\
\text { rate } \\
\text { 5. Overall mortality rate }\end{array}$ & $\begin{array}{l}\text { Calfactant reduced the rate } \\
\text { of RDS } \\
\text { and RDS-related morality, } \\
\text { but no difference in other } \\
\text { endpoints }\end{array}$ \\
\hline 2001 & $\begin{array}{l}\text { Soll et al. }[41] \\
\text { (Meta analysis) }\end{array}$ & $\begin{array}{l}\text { 1. Natural surfactant } \\
\text { 2. Synthetic protein- } \\
\text { free surfactant }\end{array}$ & $\begin{array}{l}\text { Premature neonates from } \\
11 \text { randomised control trials }\end{array}$ & $\begin{array}{l}\text { 1. Ventilator support } \\
\text { 2. Pneumothorax } \\
\text { 3. Mortality }\end{array}$ & $\begin{array}{l}\text { Natural surfactants } \\
\text { associated with } \\
\text { lower rate of all endpoints }\end{array}$ \\
\hline
\end{tabular}


Table 2. Trials Comparing Natural and Protein-Containing Synthetic Surfactants

\begin{tabular}{|c|c|c|c|c|c|}
\hline Year & Authors & Surfactants Used & Participants & Endpoints of Trial & Results of Trial \\
\hline 2005 & $\begin{array}{l}\text { Sinha et al. }[44] \\
\text { (STAR trial) }\end{array}$ & $\begin{array}{l}\text { 1. Lucinactant } \\
\text { 2. Poractant }\end{array}$ & $\begin{array}{l}252 \\
24-28 \text { weeks GA }\end{array}$ & $\begin{array}{l}\text { 1. Pneumothorax } \\
\text { 2. IVH } \\
\text { 3. Mortality rate }\end{array}$ & $\begin{array}{l}\text { Lucinactant reduced mortality rate } \\
\text { No difference in other endpoints }\end{array}$ \\
\hline 2005 & $\begin{array}{l}\text { Moya et al. }[43] \\
\text { (SELECT trial) }\end{array}$ & $\begin{array}{l}\text { 1. Lucinactant } \\
\text { 2. Beractant }\end{array}$ & $\begin{array}{l}867 \\
24-32 \text { weeks GA } \\
600-1250 \mathrm{~g}\end{array}$ & $\begin{array}{l}\text { 1. Short-term outcome } \\
\text { 2. Pneumothorax } \\
\text { 3. RDS rate } \\
\text { 4. Mortality-related to RDS }\end{array}$ & $\begin{array}{l}\text { Lucinactant reduced short-term outcome, } \\
\text { RDS rate, and RDS-related mortality, } \\
\text { but not pneumothorax and other morbidities }\end{array}$ \\
\hline
\end{tabular}

Short-term outcome: $\mathrm{O}_{2}$ requirement, duration of $\mathrm{O}_{2}$ treatment, duration of mechanical ventilation, RDS after dosing with surfactant.

and 28 weeks gestation with birth weights ranging from 600 to $1250 \mathrm{~g}$. Either lucinactant or poractant alfa was administered within 30 minutes of delivery. Results showed a reduced mortality rate at 28 days in lucinactant to that of poractant $(11.8 \%$ vs $16.1 \%)$. Patients under lucinactant treatment also reported lower mortality rates at 36 weeks post menstrual age $(16.0 \%$ vs $18.5 \%)$. Serious adverse effects were reported at similar frequency between the groups. These included bradycardia, oxygen desaturation, air leaks, intraventricular haemorrhage (IVH), and periventricular leukomalacia.

1 year after the SELECT and STAR trials were conducted, Moya et al. conducted a follow-up study on the participants [45]. A high follow-up rate was achieved at approximately $98 \%(1517 / 1546)$. In relation to the SELECT trial, mortality rates that considered loss to follow-up as a death were $28.1 \%, 31.0 \%$, and $31.0 \%$ for lucinactant, colfosceril, and beractant respectively. Results that disregarded loss to follow-up identified mortality rates of $26.6 \%, 29.1 \%$, and $28.3 \%$ for lucinactant, colfosceril, and beractant respectively. In the analysis of the STAR trial, mortality rates, which considered loss to follow-up as a death, were $19.4 \%$ for lucinactant and $24.2 \%$ poractant. Mortality rates, which did not consider loss to follow-up as a death, were $18.6 \%$ and $21.9 \%$ for lucinactant and poractant respectively. Nevertheless, the difference between the various cohorts in both trials lacked statistical significance. Results from both trials were then combined. Lucinactant reported better survival rates at 1 year in comparison to animal-derived surfactant (beractant and poractant), but again lacked significance. The authors concluded that lucinactant can provide an equal or possibly greater survival rate than animal-derived surfactants in the management of preterm infants with RDS.

\section{Comparison of Different Natural Surfactant}

With the various natural surfactant subtypes available in the market, trials have sought to compare the efficacy of these surfactants (Table 3). A meta-analysis [10] identified three trials comparing beractant to calfactant [46-48], while four trials compared beractant to poractant [49-52]. No trials evaluated the efficacy of calfactant versus poractant. Overall, calfactant and poractant were superior to beractant in terms of secondary outcomes (pneumothorax, ventilator weaning duration, need for supplemental oxygen), but rates of mortality and CLD remained similar amongst all three types. In relation to the studies comparing beractant to calfactant, no difference in the rate of mortality and oxygen requirement was identified at 36 weeks. However, infants in the calfactant cohorts reported better short-term outcomes, including duration of mechanical ventilation and number of repeat doses. Of particular interest was a publication reporting two trials involving a total sample size of 136[48]. Infants from the calfactant group reported faster weaning from mechanical ventilation and supplemental oxygen. Trials that compared beractant versus poractant identified no difference in outcomes when the same initial dose $(100 \mathrm{mg} / \mathrm{kg})$ was administered. However, when poractant was administered at an initial dose of $200 \mathrm{mg} / \mathrm{kg}$, there was a reduction in ventilator support and oxygen requirement in the poractant cohort, but no difference in other outcomes.

A more recent meta-analysis has since been carried out comparing porcine and bovine surfactants with a total of five randomised controlled trials identified, all of which compare poractant versus beractant [53]. Again, no difference is noted when the initial dose is at $100 \mathrm{mg} / \mathrm{kg}$ for both cohorts, but significant reduction in mortality and need for re-dosing has been reported in the high-dose $(200 \mathrm{mg} / \mathrm{kg})$ poractant cohort. With regards to the comparison between poractant and calfactant, no randomised controlled trial has been published. However, a retrospective study using the Premier Database (2005-2009) identified a sample size of 14173 [54]. Poractant-administered infants reported a significantly reduced rate of mortality in comparison to calfactant cohort.

\section{Comparison of Protein-Containing vs Protein-Free Synthetic Surfactant}

In the SELECT trial, findings recognized a significantly reduced incidence of RDS at 24 hours in the lucinactant cohort relative to colfosceril (39.1\% vs $47.2 \%)$ (Table 4). RDS-related mortality was significantly less common at 14 days in lucinactant as compared to colfosceril $(4.7 \%$ vs $9.4 \%$ ). In addition, BPD frequency was significantly decreased at 36 weeks post menstrual age in lucinactant than with colfosceril $(40.2 \%$ vs $45.0 \%)$. Even all-cause mortality was lower in the lucinactant cohort. However, this value lacked significance. No difference was identified among the cohorts concerning the frequency of secondary complications including air leaks, IVH, pulmonary haemorrhage, and sepsis.

\section{ADMINISTRATION OF SURFACTANT}

\section{Comparison Between Prophylactic and Rescue Therapy}

Over the years, the administration technique of surfactant has undergone a series of advances. One primary change involves the indication for surfactant. Conventional method 
Table 3. Trials Comparing Different Natural Surfactants

\begin{tabular}{|c|c|c|c|c|c|}
\hline Year & Authors & Surfactants Used & Participants & Endpoints of Trial & Results of Trial \\
\hline 1997 & Bloom et al. [47] & $\begin{array}{l}\text { 1. Beractant } \\
\text { 2. Calfactant }\end{array}$ & $\begin{array}{l}374 \text { (prevention arm) } \\
608 \text { (treatment arm) } \\
\mathrm{BW}<2000 \mathrm{~g}\end{array}$ & $\begin{array}{l}\text { 1. Short-term outcome } \\
\text { 2. Neonatal morbidity } \\
\text { 3. Neonatal mortality }\end{array}$ & $\begin{array}{l}\text { Calfactant had better } \\
\text { short-term outcome } \\
\text { both in prevention and } \\
\text { treatment arms } \\
\text { No difference in other } \\
\text { endpoints }\end{array}$ \\
\hline 2004 & Attar et al. [46] & $\begin{array}{l}\text { 1. Beractant } \\
\text { 2. Calfactant }\end{array}$ & $\begin{array}{l}40 \\
<37 \text { weeks GA }\end{array}$ & $\begin{array}{l}\text { 1. Short-term outcome } \\
\text { 2. Neonatal mortality }\end{array}$ & $\begin{array}{l}\text { Calfactant had better } \\
\text { short-term outcome } \\
\text { No difference in } \\
\text { neonatal mortality }\end{array}$ \\
\hline 2005 & Bloom et al. [48] & $\begin{array}{l}\text { 1. Beractant } \\
\text { 2. Calfactant }\end{array}$ & $\begin{array}{l}740 \text { (prevention arm) } \\
1361 \text { (treatment arm) } \\
\text { BW } 401-2000 \mathrm{~g}\end{array}$ & $\begin{array}{l}\text { 1. Short-term outcome } \\
\text { 2. } \mathrm{O}_{2} \text { requirement at } 36 \text { weeks } \\
\text { 3. Mortality rate }\end{array}$ & $\begin{array}{l}\text { Calfactant had better } \\
\text { short-term outcome } \\
\text { Other endpoints same }\end{array}$ \\
\hline 1995 & Speer et al. [52] & $\begin{array}{l}\text { 1. Beractant } \\
\text { 2. Poractant }\end{array}$ & $\begin{array}{l}73 \\
\text { BW 700-1500g }\end{array}$ & $\begin{array}{l}\text { 1. Short-term outcome } \\
\text { 2. Pneumothorax } \\
\text { 3. CLD at } 36 \text { weeks } \\
\text { 4. Mortality rate }\end{array}$ & $\begin{array}{l}\text { Poractant had better } \\
\text { short-term outcome } \\
\text { Other endpoints same }\end{array}$ \\
\hline 2003 & Baroutis et al. [49] & $\begin{array}{l}\text { 1. Beractant } \\
\text { 2. Poractant }\end{array}$ & $\begin{array}{l}53 \\
<32 \text { weeks GA } \\
\mathrm{BW}<2000 \mathrm{~g}\end{array}$ & $\begin{array}{l}\text { 1. Short-term outcome } \\
\text { 2. Air leaks } \\
\text { 3. } \mathrm{O}_{2} \text { requirement at } 36 \text { weeks } \\
\text { 4. Mortality rate }\end{array}$ & $\begin{array}{l}\text { Poractant had better } \\
\text { short-term outcome } \\
\text { Other endpoints same }\end{array}$ \\
\hline 2004 & Ramanathan et al. [51] & $\begin{array}{l}\text { 1. Beractant } \\
\text { 2. Poractant Low dose } \\
100 \mathrm{mg} / \mathrm{kg} \\
\text { High dose } 200 \mathrm{mg} / \mathrm{kg}\end{array}$ & $\begin{array}{l}293 \\
<35 \text { weeks GA } \\
\text { BW } 750-1750 \mathrm{~g}\end{array}$ & $\begin{array}{l}\text { 1. } \mathrm{O}_{2} \text { requirement at first } 6 \text { hours } \\
\text { after dosing } \\
\text { 2. Pneumothorax } \\
\text { 3. } \mathrm{O}_{2} \text { requirement at } 36 \text { weeks } \\
\text { 4. Mortality rate }\end{array}$ & $\begin{array}{l}\text { High-dose poractant } \\
\text { lower mortality rate } \\
\text { Other endpoints same }\end{array}$ \\
\hline 2005 & Malloy et al. [50] & $\begin{array}{l}\text { 1. Beractant } \\
\text { 2. Poractant } \\
\text { High dose } 200 \mathrm{mg} / \mathrm{kg}\end{array}$ & $\begin{array}{l}60 \\
<37 \text { weeks GA with RDS }\end{array}$ & $\begin{array}{l}\text { 1. Pneumothorax } \\
\text { 2. BPD at } 36 \text { weeks } \\
\text { 3. Mortality rate }\end{array}$ & $\begin{array}{l}\text { No difference in } \\
\text { endpoints }\end{array}$ \\
\hline 2011 & Singh et al. [53] & $\begin{array}{l}\text { 1. Beractant } \\
\text { 2. Poractant } \\
\text { Low dose } 100 \mathrm{mg} / \mathrm{kg} \\
\text { High dose } 200 \mathrm{mg} / \mathrm{kg}\end{array}$ & $\begin{array}{l}529 \\
<37 \text { weeks GA with RDS }\end{array}$ & $\begin{array}{l}\text { 1. } \mathrm{O}_{2} \text { requirement at } 36 \text { weeks } \\
\text { 2. Need for re-dosing } \\
\text { 3. Short-term outcome } \\
\text { 4. Mortality rate }\end{array}$ & $\begin{array}{l}\text { Poractant reduced need } \\
\text { of re-dosing, improved } \\
\text { short-term outcome, } \\
\text { and decreased } \\
\text { mortality } \\
\mathrm{O}_{2} \text { requirement at } 36 \\
\text { weeks same for both } \\
\text { groups }\end{array}$ \\
\hline 2011 & $\begin{array}{l}\text { Ramanathan et al. [54] } \\
\text { (Retrospective study) }\end{array}$ & $\begin{array}{l}\text { 1. Beractant } \\
\text { 2. Poractant } \\
\text { 3. Calfactant }\end{array}$ & $\begin{array}{l}14,173 \\
<37 \text { weeks GA with RDS }\end{array}$ & Mortality rate & $\begin{array}{l}\text { Poractant significantly } \\
\text { reduced mortality as } \\
\text { compared to calfactant } \\
\text { Poractant non- } \\
\text { significantly reduced } \\
\text { mortality as compared } \\
\text { to beractant }\end{array}$ \\
\hline
\end{tabular}

deemed surfactant administration as a means of rescue therapy. Surfactant was instilled in tandem with continued mechanical ventilation in the presence of confirmed RDS. A Cochrane meta-analysis assessed four different randomised controlled trials, with the criteria for early selective surfactant measured as administration within the first 2 hours of life [55]. Patients in the early surfactant cohort reported significantly decreased risk of pneumothorax and pulmonary emphysema. There was also a reduced incidence of neonatal mortality and CLD. No differences were demonstrated in relation to the remaining $\mathrm{RDS}$-associated complications, which included pulmonary haemorrhage, PDA, NEC, retinopathy of prematurity, and IVH of all grades. Of the four trials, the OSIRIS (Open Study of Infants at high Risk of or with respiratory Insufficiency: the role of Surfactant) trial was of particular importance due to the large sample size of 2960 [56]. Mortality rate reported a $16 \%$ reduction (early $25 \%$ vs delayed $7 \%$ ), while early administration noted a $32 \%$ lower risk of pneumothorax. 
Table 4. Trials Comparing Protein-Free and Protein-Containing Synthetic Surfactants

\begin{tabular}{|c|l|l|l|l|l|}
\hline Year & Authors & Surfactants Used & \multicolumn{1}{|c|}{ Participants } & Endpoints of Trial & \multicolumn{1}{c|}{ Results of Trial } \\
\hline \hline 2005 & Moyes et al. [43] & 1. Colfosceril & 1036 & 1. RDS rate & Lucinactant reduced RDS rate and BPD \\
& & 2. Lucinactant & B. BPD weeks GA & No difference in mortality \\
& & & BW $600-1250 \mathrm{~g}$ & \\
\hline
\end{tabular}

Other studies include a multicentre, randomised, placebocontrolled trial that identified no difference in the rate of RDS or RDS-associated mortality between prophylactic and rescue-eligible cohorts [57]. Another trial involving neonates between the gestational age of 26 to 29 weeks were divided into prophylaxis (within 10 minutes of birth, $n=75$ ) and rescue (placebo dose at 10 minutes, $\mathrm{n}=72$ ) groups [11]. Poractant $\left(\right.$ Curosurf $\left.^{\mathbb{B}}\right)$ was administered intratracheally. The results identified an RDS rate of $19 \%$ in prophylaxis versus $32 \%$ in rescue cohort $(\mathrm{p}<0.05)$. At six hours, significantly greater tc $\mathrm{PO}_{2} / \mathrm{FI}_{2}$ (transcutaneous oxygen tension/fraction of inspired oxygen) was identified in the prophylaxis group $(p<0.001)$. There were no differences in incidence or severity of pneumothorax, cerebral haemorrhage, periventricular leukomalacia, PDA, and mortality.

\section{Comparison Between Single and Multiple Doses of Surfactant}

The possibility of administering multiple doses of surfactant as a means to reduce the risk of RDS and its related complications has been trialled by a number of authors. A Cochrane meta-analysis was subsequently compiled with three randomised control trials identified [8]. A total of 1244 infants were recruited (Dunn $n=75$, Speer $\mathrm{n}=343$, Corbet $\mathrm{n}=826$ ). Bovine, porcine, and synthetic surfactant were all used with up to three additional doses allowed in the multiple-doses cohorts. All three trials demonstrated a greater reduction in the risk of mortality in infants receiving multiple doses with Corbet (synthetic surfactant) reporting a statistically significant reduction. A more consistent improvement in oxygenation and a greater reduction in the rate of ventilator support were reported in the multiple doses cohort. Administration of multiple doses was also found to significantly lower the risk of NEC. There was no statistically significant difference in the risk of pneumothorax, pulmonary haemorrhage, PDA, IVH, bacterial sepsis, and BPD. No complications were found to be associated with the administration of multiple surfactant doses.

Despite the positive findings from the meta-analysis, there have been trials contradicting these reports. 75 infants at $<30$ weeks gestation underwent single or multiple INSURE (INtubation, SURfactant, Extubation) procedures depending on the decision of the neonatologist on duty [58]. There was no significant difference in respiratory outcome with similar rates of failure, mechanical ventilation, and BPD incidence. It is important to note that in comparison to the single INSURE procedure cohort, infants from the multiple INSURE group had lower gestational age and birthweight, more severe RDS, higher incidence of PDA, and longer duration of oxygen therapy. Therefore, the efficacy of multiple INSURE procedures has yet to be fully understood. Additionally, the optimal number of doses is still unclear. The OSIRIS trial reported that efficacy following a third and fourth dose was no different from the effect after two doses [56].

\section{RECENT DEVELOPMENT}

\section{Ventilation with Nasal Continuous Positive Airway Pressure: Prophylactic vs Selective Use of Surfactant}

Despite the crucial benefit mechanical ventilation affords in RDS, there are several complications that can arise including pneumothorax, airway injury, and ventilatorassociated pneumonia. Therefore, methods that reduce the requirement for mechanical ventilation are welcome. Nasal continuous positive airway pressure (nCPAP) is one such technique that has been developed. One study reported a reduction in median intubation duration of 1.5 days after nCPAP was introduced, along with a $23 \%$ reduction in intubation rate [59]. Bi-level nasal CPAP (BiPAP) has since been trialled with better respiratory outcomes compared to nCPAP [60]. Duration of expiratory support, $\mathrm{O}_{2}$ dependency, and in-patient stay were all reduced in infants assigned to BiPAP. However, there were no differences in the rate of survival, BPD, and neurological disorders. Nasal intermittent positive-pressure ventilation (NIPPV) is another ventilation technique that provides an alternative to mechanical ventilation by combining nCPAP with intermittent ventilator breaths. A single-centre, randomised control trial of 200 infants demonstrated no significant difference between NIPPV and nCPAP in terms of need for mechanical ventilation [61]. However, retrospective trials evaluating other outcomes including BPD, neurodevelopmental impairment, and death have found a reduced incidence in NIPPV compared to nCPAP $[62,63]$.

In recent years, a new technique for prophylactic administration of surfactant has been trialled. Surfactant was administered via endotracheal instillation during a brief period of mechanical ventilation with subsequent extubation. nCPAP could follow extubation if deemed necessary. This process of early surfactant intervention was referred to as the INSURE (INtubation, SURfactant, Extubation) technique. It was hypothesised that this early treatment strategy could prevent or reduce the severity of RDS and its related complications. Trials have confirmed the findings with infants from the INSURE method demonstrating significant reduction in duration of oxygen therapy and mechanical ventilation [64], while a bicentre trial concerning 420 premature infants reported a $50 \%$ reduction in the incidence of mechanical ventilation $(p<0.01)$ [65]. A Cochrane metaanalysis that analysed trials up to 2006 identified 6 randomised controlled trials which compared the impact of surfactant administration by prophylactic means (within 1 hour of life) versus conventional method [66]. Compared to later selective surfactant administration, early surfactant therapy was associated with a lower rate of mechanical 
ventilation, air leak syndromes, and BPD. A significant increase in the incidence of PDA was found in selective conventional therapy. It is important to note that in the three trials reporting this outcome, the number of surfactant doses per patient was significantly greater in the early surfactant group. In terms of mean duration of mechanical ventilation, three studies reported no statistical difference between the two cohorts though there was a trend toward early surfactant administration. No significant difference was identified in terms of neonatal mortality, IVH, periventricular luekomalacia, pulmonary haemorrhage, or NEC.

However, INSURE carries a significant disadvantage that may expose neonates to unnecessary intubation procedure or surfactant administration since some infants may not suffer from RDS and will not require intubation or surfactant. An idea has been proposed supporting the selective use of surfactant alongside routine nCPAP procedure for all preterm neonates. They will be stabilised and maintained with nCPAP, with intubation and surfactant only indicated in the early signs of RDS. The DRM study revealed that selective treatment resulted in $48 \%$ infants avoiding intubation and ventilation, while $54 \%$ did not required surfactant treatment [67]. Nevertheless, there was no difference in neonatal morbidity and mortality when compared to infants with prophylactic surfactant. The CURPAP trial was an international, multicentre, Phase IV study comparing prophylactic and selective use of surfactant in 208 neonates with a gestational age of 25 to 28 weeks [68]. The results identified that of the infants in the selective cohort, only $48.5 \%$ required intubation and surfactant administration, while only $33 \%$ required mechanical ventilation. A more recent meta-analysis of 11 studies demonstrates the advantages of selective surfactant administration in reducing the risk of chronic lung disease and infant mortality rate [69].

\section{Mode of Surfactant Administration}

With the benefits of surfactant well established, advances are underway to improve the mechanism of surfactant administration. Tracheal intubation is currently the common method, but with the complications involved in this procedure, a non-invasive method of administration has been sought. The difficulty involved in development relates to the packaging of surfactant. To pass through the airways and reach the alveoli, surfactant must be compressed into an appropriate size without permanently compromising the structural integrity. Once at the alveoli, surfactant should expand and regain molecular configuration. In spite of the logistical difficulty, such a method has been developed. Aerosurf $^{\mathbb{R}}$ is a new device, which involves the inhalation of aerosolised lucinactant through a vibrating membrane nebuliser. A pilot study was carried out on 17 premature neonates of $<32$ weeks gestation in 4 US centres [70]. Administration of lucinactant occurred within 30 minutes of delivery over a 3 hour duration. The procedure was well tolerated with no mortality. Only 6 infants required endotracheal intubation with intratracheal instillation of surfactant. Moreover, the only significant complication noted was the transient desaturation in oxygen concentration. However, this phenomenon has also been reported in trials involving surfactant administration via tracheal intubation $[39,44]$. Further studies are required especially to compare the efficacy of conventional intratracheal administration versus inhalation technique. Additionally, the volume required for desired effect has yet to be determined since a certain proportion will not reach the alveoli. New surfactants are being developed to increase optimisation of aerosol administration. This includes the formation of aerosol nanovesicles to improve resistance to surfactant inactivation [71].

Gopel et al. recently introduced another mode of instillation whereby surfactant was administered via a thin catheter placed by laryngoscopy into the trachea [72]. 220 preterm infants were recruited in a multicentre, open-label trial and randomised to the intervention group or the standard treatment group, which received surfactant via intubation. The intervention cohort reported significantly reduced duration of mechanical ventilation and rate of oxygen therapy in comparison to the standard treatment group. No significant differences were noted in terms of mortality and serious adverse effects. Nevertheless, the prospect of administering surfactant to spontaneouslybreathing infants without intubation is promising.

Another mode of surfactant administration involves a laryngeal mask airway (LMA). The LMA is a supraglottic device that contains a curved plastic tube with an inflatable mask. The mask can be placed blindly into the posterior pharynx and inflated to seal off the oesophagus. Surfactant is administered through the created airway. A Cochrane review identified a single study in which 26 premature infants with body weight $\geq 1200 \mathrm{~g}$ and diagnosed with RDS were administered nCPAP [73]. Surfactant was provided through LMA. The result demonstrated a decrease in mean $\mathrm{FiO}_{2}$ requirement to maintain oxygen saturation between $88 \%$ and $92 \%$ for 12 hours, but there was no difference in the requirement of mechanical ventilation.

Researchers have also entertained the idea of surfactant administration during pregnancy. A device enters the amniotic fluid and instils surfactant near the mouth and nasal region of the foetus. It is hoped that this strategy may help prevent RDS development and avoid endotracheal intubation. A Cochrane meta-analysis searched for trials pertaining to intra-amniotic administration of surfactant in women at risk of preterm birth [74]. Risk factors for preterm birth included ruptured membrane, cervical incompetence, pre-eclampsia, growth restriction, and antepartum haemorrhage. The procedure involved percutaneous amniocentesis under ultrasound guidance or transvaginal instillation through fiberscope. Caesarean section was carried out within 180 minutes of the procedure. No trials fit the inclusion criteria, but a number of observational studies were identified [75-77]. Neonates administered intraamniotic surfactant demonstrated a reduced incidence of RDS. No major maternal or neonatal complications or infections were highlighted. Intra-partum administration is another prophylactic technique that has been trialled [78]. Calfactant was instilled into the nasopharynx prior to delivery of the shoulders in 23 neonates born between 27 and 30 weeks. Of the 15 infants delivered vaginally, 13 required no endotracheal intubation, while three of the eight babies delivered by Caesarean section did not undergo intubation. Randomised control trials with a larger sample size are needed to confirm these findings. 


\section{Synthetic Surfactant Containing SP-B and SP-C}

Apart from advances in administration technique, surfactant proteins are also being developed. Surfactant combined with recombinant SP-C (rSP-C) is currently being developed, but has not reached clinical trials in neonates $[79,80]$. rSP-C has, however, been tested on adults with acute RDS who have demonstrated improved oxygenation [81]. By itself, SP-C containing surfactant can achieve similar tidal volumes as poractant, but it requires ventilation with positive end-expiratory pressure (PEEP) to prevent alveolar collapse. The combination of SP-B to the molecule has been shown to stabilise newborn rabbit alveoli at endexpiration without the need for PEEP $[82,83]$. Similarly, SPA containing surfactant is another possibility. Studies on SPA knockout mice identified an increase in alveolar macrophage proteome expression following SP-A induction [84]. The addition of ionic and non-ionic polymers to a surfactant mixture is another proposed mechanism to enhance molecule stability [85]. These polymers include hylauronan (HA), chitosan, polyethylene glycol (PEG), dextran, and polymyxin. Minimum surface tension at the $10^{\text {th }}$ cycle was $16 \mathrm{mN} / \mathrm{m}$ with $\mathrm{HA}$ addition in comparison to $34 \mathrm{mN} / \mathrm{m}$ with PEG addition. $(\mathrm{p}<0.001)$. Threshold of inhibition was also raised upon HA administration to the lipid mixture $(350 \mu \mathrm{g} / \mathrm{ml}$ for polymer-free lipid mixtures with or without $\mathrm{KL}_{4}, 350-700 \mu \mathrm{g} / \mathrm{ml}$ for HA $250 \mathrm{kDa}$ lipid mixture, $700-1050 \mu \mathrm{g} / \mathrm{ml}$ for HA $250 \mathrm{kDa}$ and PEG lipid mixture, $>1400 \mu \mathrm{g} / \mathrm{ml}$ for addition of HA $1240 \mathrm{kDa}$ to HA $250 \mathrm{kDa}$ and PEG lipid mixture). Several theories have been offered to explain the ameliorated surfactant inhibition by serum. First, HA and PEG have high hydrophilic properties, which is thought to isolate inhibitors from surfactant molecule. Second, the charged presence of HA and PEG may compress the surfactant interface preventing serum proteins from disrupting the structure.

\section{CONCLUSION}

While the efficacy of surfactant in the prevention and treatment of RDS has been well-documented, issues remain. These include surfactant type, as well as the mode and timing of administration. For the time being, natural surfactant is the surfactant of choice, but a superior subtype is still debatable. However, the development of synthetic surfactant containing peptides that mimic the action of surfactant proteins have demonstrated a similar, if not superior, efficacy to natural surfactant. It is hoped that further development will allow synthetic surfactant to supersede natural surfactant, resulting in a reliable, wellcontrolled product that will be more cost-effective and prevent the risk of immunogenicity. Lucinactant, a synthetic surfactant with a KL4 peptide that mimics SP-B, is currently awaiting U.S. Food and Drug Administration (FDA) approval for commercial use; a decision will be announced in March 2012 [38]. Besides, SP-B and SP-C containing surfactant may represent an important development of surfactant.

With regards to the mode and timing of surfactant administration, early surfactant instillation demonstrated greater impact in reducing the risk of RDS and its related complications. The INSURE technique is quickly becoming standard procedure in the management of RDS. Since
nCPAP has become the first-line management of RDS, this approach along with early selective surfactant appears to provide a better option as illustrated in recent studies. Instillation is currently via endotracheal tube, but noninvasive methods are being trialled including aerosolised form. Clearly further research and development into surfactant therapy is needed as more innovations are introduced, but its therapeutic potential in RDS is promising.

\section{AUTHORS BIOGRAPHY}

Christopher Cheng-Hwa Ma is a medical student in his penultimate year at King's College London School of Medicine. He has participated in a number of studies related to managing cardiorespiratory disorders and recently published a review discussing the cardiorespiratory impact of statins.

Sze Ma is a physician of over thirty years. He has been awarded an FRCOG, FHKCOG, DCH (NUI), and DCH (RCP\&SI). His constant interest in child health has offered him a privileged insight into the various neonatal disorders that impact healthcare.

\section{ACKNOWLEDGEMENT}

We thank Jonathan Ma for his help in the formatting and drafting of the manuscript.

\section{CONFLICT OF INTEREST}

The authors confirm that this article content has no conflicts of interest.
ABBREVIATIONS
$\mathrm{BW}=$ Birth weight
$\mathrm{GA}=$ Gestational age
CLD $=$ Chronic lung disease
$\mathrm{BPD}=$ Bronchopulmonary dysplasia
IVH $=$ intraventricular haemorrhage

\section{REFERENCES}

[1] Burri PH. Fetal and postnatal development of the lung. Ann Rev Physiol 1984; 46: 617-28.

[2] Clements JA. Surface tension of lung extracts. Proc Soc Exp Biol Med 1957; 95: 170-2

[3] Avery ME, Mead J. Surface properties in relation to atelectasis and hyaline membrane disease. AMA J Dis Child 1959; 97: 517-23.

[4] Lemons JA, Bauer CR, Oh W, et al. Very low birth weight outcomes of the National Institute of Child health and human development neonatal research network, January 1995 through December 1996. NICHD Neonatal Research Network. Pediatrics 2001; 107: E1.

[5] Farrell PM, Wood RE. Epidemiology of hyaline membrane disease in the United States: analysis of national mortality statistics. Pediatrics 1976; 58: 167-76.

[6] Fujiwara T, Maeta H, Chida S, Morita T, Watabe Y, Abe T. Artificial surfactant therapy in hyaline-membrane disease. Lancet 1980; 12: 55-9.

[7] Halliday HL. Surfactants: past, present and future. J Perinatol 2008; 28 (Suppl 1): S47-56

[8] Soll R, Ozek E. Multiple versus single doses of exogenous surfactant for the prevention or treatment of neonatal respiratory distress syndrome. Cochrane Database Syst Rev 2009; CD000141.

[9] Cummings JJ, Holm BA, Hudak ML, Hudak BB, Ferguson WH, Egan EA. A controlled clinical comparison of four different surfactant preparations in surfactant- deficient preterm lambs. Am Rev Respir Dis 1992; 145: 999-1004. 
[10] Logan JW, Moya FR. Animal-derived surfactants for the treatment and prevention of neonatal respiratory distress syndrome: summary of clinical trials. Ther Clin Risk Manag 2009; 5: 251-60.

[11] Egberts J, de Winter JP, Sedin G, et al. Comparison of prophylaxis and rescue treatment with Curosurf in neonates less than 30 weeks' gestation: a randomised trial. Pediatrics 1993; 92: 768-74.

[12] Zola EM, Overbach AM, Gunkel JH, et al. Treatment Investigational New Drug experience with Survanta (beractant). Pediatrics 1993; 91: 546-51.

[13] Onrust SV, Dooley M, Goa KL. Calfactant: a review of its use in neonatal respiratory distress syndrome. Paediatr Drugs 1999; 1: 219-43.

[14] Durand DJ, Clyman RI, Heymann MA, et al. Effects of a proteinfree, synthetic surfactant on survivial and pulmonary function in preterm lambs. J Pediatr 1985; 107: 775-80.

[15] Cochrane CG, Revak SD, Merritt TA, et al. The efficacy and safety of KL-4 surfactant in preterm infants with respiratory distress syndrome. Am J Respir Crit Care Med 1996; 153: 404-10.

[16] Moya F. Synthetic surfactants: where are we? Evidence from randomized, controlled clinical trials. J Perinatol 2009; 29(Suppl 2): S23-8.

[17] Seurynck-Servoss SL, Brown NJ, Dohm MT, Wu CW, Barron AE. Lipid composition greatly affects the in vitro surface activity of lung surfactant protein mimics. Colloids Surf B Biointerfaces 2007; 57: 37-55.

[18] Gerber F, Krafft MP, Vandamme TF, Goldmann M, Fontaine P. Potential use of fluorocarbons in lung surfactant therapy. Artif Cells Blood Substit Immobil Biotechnol 2007; 35: 211-20.

[19] Sano H, Kuroki Y. The lung collectins, SP-A and SP-D, modulate pulmonary innate immunity. Mol Immunol 2005; 42: 279-87.

[20] Ramadas RA, Wu L, LeVine AM. Surfactant protein A enhances production of secretory leukoprotease inhibitor and protects it from cleavage by matrix metalloproteinases. J Immunol 2009; 182: 15607.

[21] Kresch MJ, Block M, Karim MR, et al. Surfactant protein A stimulates release of neutrophil chemotactic factors by alveolar type II pneumocytes. Lung 2010; 188: 491-7.

[22] Awasthi S, Coalson JJ, Yoder BA, Crouch E, King RJ. Deficiencies in lung surfactant proteins $\mathrm{A}$ and $\mathrm{D}$ are associated with lung infection in very premature neonatal baboons. Am J Respir Crit Care Med 2001; 163: 389-97.

[23] Atochina EN, Gow AJ, Beck JM, et al. Delayed clearance of pneumocystis carinii infection, increased inflammation, and altered nitric oxide metabolism in lungs of surfactant protein-D knockout mice. J Infect Dis 2004a; 189: 1528-39.

[24] Atochina EN, Beck JM, Preston AM, et al. Enhanced lung injury and delayed clearance of Pneumocystis carinii in surfactant protein A-deficient mice: attenuation of cytokine responses and reactive oxygen-nitrogen species. Infect Immun 2004b; 72: 6002-11.

[25] Lemos MP, McKinney J, Rhee KY. Dispensability of surfactant proteins $\mathrm{A}$ and $\mathrm{D}$ in immune control of Mycobacterium tuberculosis infection following aerosol challenge of mice. Infect Immun 2011; 79: 1077-85.

[26] Hickman-Davis JM, Wang Z, Fierr-Perez GA, et al. Surfactant dysfunction in SP-A-/- and iNOS-/- mice with mycoplasma infection. Am J Respir Cell Mol Biol 2007; 36: 103-13.

[27] Ballard PL, Merrill JD, Godinez RI, Godinez MH, Truog WE, Ballard RA. Surfactant protein profile of pulmonary surfactant in premature infants. Am J Respir Crit Care Med 2003; 168: 1123-8.

[28] Antharam VC, Farver RS, Kuznetsova A, et al. Interactions of the C-terminus of lung surfactant protein B with lipid bilayers are modulated by acyl chain saturation. Biochim Biophys Acta 2008; 1778: 2544-54.

[29] Schurch D, Ospina OL, Cruz A, Perez-Gil J. Combined and independent action of proteins SP-B and SP-C in the surface behaviour and mechanical stability of pulmonary surfactant films. Biophys J 2010; 99: 3290-9.

[30] Wallot M, Wagenvoort C, deMello D, Muller KM, Floros J, Roll C. Congenital alveolar proteinosis caused by a novel mutation of the surfactant protein B gene and misalignment of lung vessels in consanguineous kindred infants. Eur J Pediatr 1999; 158: 513-8.

[31] Williams GD, Christodoulou J, Stack J, et al. Surfactant protein B deficiency: clinical, histological and molecular evaluation. J Paediatr Child Health 1999; 35: 214-20.

[32] Nogee LM. Alterations in SP-B and SP-C expression in neonatal lung disease. Ann Rev Phsyiol 2004; 66: 601-23.
[33] Survanta ${ }^{\circledR}$ (beractant) Intratracheal Suspension prescribing information. Abbot Laboratories, Inc. March 2009.

[34] Infasurf ${ }^{\mathbb{B}} \quad$ (calfactant) Intratracheal Suspension prescribing information. ONY, Inc. June 2009

[35] Wang Z, Baatz JE, Holm BA, Notter RH. Content-dependent activity of lung surfactant protein B in mixtures with lipids. Am J Physiol Lung Cell Mol Physiol 2002; 5: L897-906.

[36] Curosurf ${ }^{\circledR}$ (poractant alfa) Intratracheal Suspension prescribing information, Cornerson Therapeutics Inc. September 2009.

[37] Curstedt T, Johansson J. New synthetic surfactants: basic science. Biol Neonate 2005; 87: 3327.

[38] Discovery Laboratories, Inc. Discovery Labs Notified of PDUFA Date for SURFAXIN. Pennsylvania September 28 2011. Available from: http://www.discovery labs.com/2011 pr/092811-PR.pdf [Viewed: December 20, 2011]

[39] Lal MK, Sinha SK. Surfactant respiratory therapy using Surfaxin/sinapultide. Ther Adv Respir Dis 2008; 2: 339-44.

[40] Zhu Y, Miller TL, Chidekel A, Shaffer TH. KL4-surfactant (Lucinactant) protects human airway epithelium from hyperoxia. Pediatr Res 2008; 64: 154-8.

[41] Soll RF, Blanco F. Natural surfactant extract versus synthetic surfactant for neonatal respiratory distress syndrome. Cochrane Database Syst Rev 2001; 2: CD000144.

[42] Hudak ML, Martin DJ, Egar EA, et al. A multicenter randomized masked comparison trial of synthetic surfactant versus calf lung surfactant extract in the prevention of neonatal respiratory distress syndrome. Pediatrics 1997; 100: 39-50.

[43] Moya FR, Gadzinowski J, Bancalari E, et al. A multicentrer, randomized, masked, comparison trial of lucinactant, colfosceril palmitate, and beractant for the prevention of respiratory distress syndrome among very preterm infants. Pedatrics 2005; 115: 101829.

[44] Sinha SK, Lacaze-Masmonteil T, Vallis i Soler A, et al. A multicenter, randomized, controlled trial of lucinactant versus proactant alfa among very premature infants at high risk for respiratory distress syndrome. Pediatrics 2005; 115: 1030-8.

[45] Moya FR, Sinha S, Gadwinowski J, et al. One-year follow-up of very preterm infants who received lucinactant for prevention of respiratory distress syndrome: results from 2 multicenter randomized, controlled trials. Pediatrics 2007; 119: e1361-70.

[46] Attar MA, Becker MA, Dechert RE, Donn SM. Immediate changes in lung compliance following natural surfactant administration in premature infants with respiratory distress syndrome: a controlled trial. J Perinatol 2004; 24: 626-30

[47] Bloom BT, Kattwinkel J, Hall RT, et al. Comparison of infasurf (calf lung surfactant extract) to survanta with surfactant protein $\mathrm{b}$ deficiency. J Pediatr 1997; 130: 231-9.

[48] Bloom BT, Clark RH, Infasurf Survanta Clinical Trial Group. Comparison of Infasurf (calfactant) and Survanta (beractant) in the prevention and treatment of respiratory distress syndrome. Pediatrics 2005; 116: 392-9.

[49] Baroutis G, Kaleyias J, Liarou T, Papathoma E, Hatzistamatiou Z, Costalos C. Comparison of three treatment regimens of natural surfactant preparations in neonatal respiratory distress syndrome. Eur J Pediatr 2003; 162: 476-80.

[50] Malloy CA, Nicoski P, Muraskas JK. A randomized trial comparing beractant and poractant treatment in neonatal respiratory distress syndrome. Acta Paediatr 2005; 94: 779-84.

[51] Ramanathan R, Rasmussen MR, Gerstmann DR, Finer N, Sekar K A randomized, multicenter masked comparison trial of poractant alfa (curosurf) versus beractant (survanta) in the treatment of respiratory distress syndrome in preterm infants. Am J Perinatol 2004; 21: 109-19.

[52] Speer CP, Gefeller O, Groneck P, et al. Randomised clinical trials of two treatment regimens of natural surfactant preparations in neonatal respiratory distress syndrome. Arch Dis Child Fetal Neonatal Ed 1995; 72: F8-13.

[53] Singh N, Hawley KL, Viswanathan K. Efficacy of porcine versus bovine surfactants for preterm newborns with respiratory distress syndrome: systematic review and meta-analysis. Pediatrics 2011 128: e1588-95

[54] Ramanathan R, Bhatia JJ, Sekar K, Ernst FR. Mortality in preterm infants with respiratory distress syndrome treated with poractant alfa, calfactant or beractant: a retrospective study. J Perinatol 2011; doi 10.1038[Epub ahead of print] 
[55] Yost CC, Soll RF. Early versus delayed selective surfactant treatment for neonatal respiratory distress syndrome. Cochrane Database Syst Rev 2000; 2: CD001456.

[56] The OSIRIS (open study of infants at high risk of or with respiratory insufficiency: the role of surfactant) Collaborative Group. Early versus delayed neonatal administration of a synthetic surfactant - the judgment of OSIRIS. Lancet 1992; 340: 1363-9.

[57] Merritt TA, Hallman M, Berry C, et al. Randomised, placebocontrolled trial of human surfactant given at birth versus rescue administration in very low birth weight infants with lung immaturity. J Pediatr 1991; 118: 581-94.

[58] Dani C, Corsini I, Bertini G, Pratesi S, Barp J, Rubaltelli FF. Effect of multiple INSURE procedures in extremely preterm infants. J Matern Fetal Neonatal Med 2011; 24: 1427-31.

[59] Gittermann MK, Fusch C, Gittermann AR, Regazzoni BM, Moessinger AC. Early nasal continuous positive airway pressure treatment reduces the need for intubation in very low birth weight infants. Eur J Pediatr 1997; 156: 383-8.

[60] Lista G, Castoldi F, Fontana P, et al. Nasal continuous positive airway pressure (CPAP) versus bi-level nasal CPAP in preterm babies with respiratory distress syndrome: a randomised control trial. Arch Dis Child Fetal Neonatal Ed 2010; 95: F85-9.

[61] Meneses J, Bhandari V, Alves JG, Herrmann D. Noninvasive ventilation for respiratory distress syndrome: a randomized controlled trial. Pediatrics 2011; 127: 300-7.

[62] Bhandari V, Finer NN, Ehrenkranz RA, et al. Synchronized nasal intermittent positive-pressure ventilation and neonatal outcomes. Pediatrics 2009; 124: 517-26.

[63] Davis PG, Morley CJ, Owen LS. Non-invasive respiratory support of preterm neonates with respiratory distress: continuous positive airway pressure and nasal intermittent positive pressure ventilation. Semin Fetal Neonatal Med 2009; 14: 14-20.

[64] Dani C, Bertini G, Pezzati M, Cecchi A, Caviglioli C, Rubaltelli FF. Early extubation and nasal continuous positive airway pressure after surfactant treatment for respiratory distress syndrome among preterm infants $<30$ weeks' gestation. Pediatrics 2004; 113: 560-3.

[65] Bohlin K, Gudmundsdottir T, Katz-Salamon M, Jonsson B, Blennow M. Implementation of surfactant treatment during continuous positive airway pressure. J Perinatol 2007; 27: 422-7.

[66] Stevens TP, Harrington EW, Blennow M, Soll RF. Early surfactant administration with brief ventilation versus selective surfactant and continued mechanical ventilation for preterm infants with or at risk for respiratory distress syndrome. Cochrane Database Syst Rev 2008; CD003063.

[67] Dunn MS, Kaempf J, de Klerk R, et al. Randomized trial comparing 3 approaches to initial respiratory management of preterm neonates. Pediatrics 2011; 5: e1069-76.

[68] Sandri F, Plavka R, Ancora G, et al. Prophylactic or early selective surfactant combined with nCPAP in very preterm infants. Pediatrics 2010; 6: 1402-9.

[69] Rojas-Reyes MX, Morley CJ, Soll R. Prophylactic versus selective use of surfactant in preventing morbidity and mortality in preterm infants. Cochrane Database Syst Rev 2012; 3: CD000510.

[70] Finer NN, Merritt TA, Bernstein G, Job L, Mazela J, Segal R. An open label, pilot study of Aerosurf combined with nCPAP to prevent RDS in preterm neonates. J Aerosol Med Pulm Drug Deliv 2010; 23: 303-9.

[71] Kaviratna AS, Banerjee R. Nanovesicle aerosols as surfactant therapy in lung injury. Nanomedicine 2012; 8(5): 665-72.

[72] Gopel W, Kribs A, Ziegler A, et al. Avoidance of mechanical ventilation by surfactant treatment of spontaneously breathing preterm infants (AMV): an open-label, randomised, controlled trial. Lancet 2011; 378: 1627-34.

[73] Abdel-Latif ME, Osborn DA. Laryngeal mask airway surfactant administration for prevention of morbidity and mortality in preterm infants with or at risk of respiratory distress syndrome. Cochrane Database Syst Rev 2011; 7: CD008309.

[74] Abdel-Latif ME, Osborn DA, Challis D. Intra-amniotic surfactant for women at risk of preterm birth for preventing respiratory distress in newborns (Review). Cochrane 2010; 1: CD007916,

[75] Zhang JP, Wang YI, Wang YH, Zhang R, Cheng H, Su HB. Prophylaxis of neonatal respiratory distress syndrome by intraamniotic administration of pulmonary surfactant. Chin Med J (Engl) 2004; 117: 120-4.

[76] Petrikovsky BM, Lysikiewicz A, Markin LB, Slomko Z. In utero surfactant administration to preterm human foetuses using endoscopy. Fetal Diagn Ther 1995; 10: 127-30.

[77] Cosmi EV, La Torre R, Piazze JJ, Maranghi GL, Lero N, Bianco D, Anceschi MM. Intraamniotic surfactant for prevention of neonatal respiratory distress syndrome (IRDS): rationale and personal experience. Eur J Obstet Gynecol Reprod Biol 1997; 71: 135-9.

[78] Kattwinkel J, Robinson M, Bloom BT, Delmore P, Ferguson JE. Technique for intrapartum administration of surfactant without requirement for an endotracheal tube. J Perinatol 2004; 24: 360-5.

[79] Brown NJ, Dohm MT, de la Serna JB, Barron AE. Biomimetic Nterminal alkylation of peptoid analogues of surfactant protein $\mathrm{C}$. Biophys J 2011; 101: 1076-85.

[80] Johansson J, Some M, Linderholm BM, Almlen A, Curstedt T, Robertson B. A synthetic surfactant based on a poly-Leu SP-C analog and phospholipids: effects on tidal volumes and lung gas volumes in ventilated immature newborn rabbits. J Appl Physiol 2003; 95: 2055-63.

[81] Taut FJ, Rippin G, Schenk P, et al. A search for subgroups of patients with ARDS who may benefit from surfactant replacement therapy: a pooled analysis of five studies with recombinant surfactant protein-C surfactant (Venticute). Chest 2008; 134: 72432.

[82] Curstedt T, Johnansson J. Different effects of surfactant proteins B and $\mathrm{C}$ - implications for development of synthetic surfactants. Neonatology 2010; 97: 367-72.

[83] Almlen A, Walther FJ, Waring AJ, Robertson B, Johansson J, Curstedt T. Synthetic surfactant based on analogues of SP-B and SP-C is superior to single-peptide surfactants in ventilated premature rabbits. Neonatology 2010; 98: 91-9.

[84] Phelps DS, Umstead TM, Quintero OA, Yengo CM, Floros J. In vivo rescue of alveolar macrophages from SP-A knockout mice with exogenous SP-A nearly restores a wild type intracellular proteome; actin involvement. Proteome Sci 2011; $28: 67$.

[85] Lu KW, Taeusch HW. Combined effects of polymers and KL(4) peptide in surface activity of pulmonary surfactant lipids. Biochim Biophys Acta 2010; 1798: 1129-34. 